\title{
AN EMERGENCY RESPONSE DECISION MATRIX AGAINST TERRORIST ATTACKS WITH IMPROVISED DEVICE IN CHEMICAL CLUSTERS
}

\author{
BEHNAZ HOSSEINNIA, NIMA KHAKZAD \& GENSERIK RENIERS \\ Safety and Security Science Group, Delft University of Technology, The Netherlands.
}

\begin{abstract}
Chemical industrial areas may constitute potential targets for deliberate actions by terrorists. Terrorists having sufficient knowledge of chemical process operations or plant layout may take advantage of improvised explosive devices (IEDs) to cause major events such as fire, explosion and toxic gas dispersion with cross-border consequences in chemical clusters. Thus, an efficient cluster-wise emergency plan to enhance the promptness and efficacy of responding to such attacks is crucial. In this study, the effects of blast wave caused by IEDs are assessed and its potentiality in triggering domino scenarios are analysed. A decision tree is developed to determine the emergency level of each company within the cluster based on the attack outcomes. Furthermore, an alert notification system is set based on a decision matrix. Finally, the identified emergency levels and the alert levels are presented in form of a multi-plant decision matrix. The application of the developed methodology is demonstrated in a case study.

Keywords: chemical industrial area, decision matrix, decision tree, emergency response, improvised explosive device, terrorist attack
\end{abstract}

\section{INTRODUCTION}

Prior to 9/11 attacks, terrorist threats had been recognized for a long time, but a successful terrorist attack on chemical plants was assumed to be quite unlikely [1]. However, the security risks has become an important concern for the chemical industry ever since [2,3].

Chemical industrial areas due to handling large quantities of hazardous chemicals are potential targets for deliberate actions by terrorists. Compared to safety accidents in the chemical industry, security events could be much worse in terms of the extent and severity and may affect many people in nearby communities. Despite recent concerns about weapons of mass destruction (WMD), explosions are by far the most common cause of mass-casualty incidents associated with terrorism [4]. A successful attack aimed at direct or indirect damage of target equipment by bombs or fire arms can trigger domino scenarios [5] and cause damages to multiple process units or eventually several neighbouring industrial site [6, 7]. The terrorist attacks to Iraq's oil terminal in 2004 and largest refinery in 2015 are examples of terrorist attacks by improvised explosive devices (IEDs) to chemical plants [8, 9]. IEDs are unconventional kinds of bombs usually carried or delivered in a vehicle, package, by a person, or concealed on the roadside [10].

A number guideline and approaches have been proposed regarding the emergency response and preparedness for security threats in chemical industry such as [11], but there is no specific procedure available for managing terrorist attacks in multi-plant chemical industrial areas. Thus, an efficient cluster-wise emergency response seems crucial for enhancing the promptness of reacting to the attack. In this regard, the present study is aimed at introducing an innovative multi-plant response decision matrix that creates an overview of emergency levels and alert levels for individual plants within a cluster in order to help them respond in a pre-agreed procedure to terrorist attacks with IEDs. Each emergency level indicates the 
potential actions that an individual could adopt to prepare for and respond to catastrophic terrorist attacks. The alert levels can help the security decision makers plan for increasing the security of other critical assets in the chemical cluster in the prospect of imminent threats or attacks in the future.

The developed methodology is presented in the next section. The application of the methodology is illustrated in Section 3, while Section 4 concludes the paper.

\section{METHODOLOGY}

2.1 Overview of the methodology

The approach is based on five main components which are (i) identifying the target assets, (ii) developing and analysing the most likely attack scenarios, (iii) determining the emergency levels, (iv) developing alert notification system and (v) establishing cluster decision matrix.

\subsection{Identifying the target assets}

In security terms, assets for a chemical facility are defined as people (both on-site and offsite), information (trade secrets, confidential business information and etc.) and property (buildings, process equipment, control systems and etc.) [12]. Not all assets have equal value to adversaries [13]. In the first step, the assets of each company are identified, and then, they are prioritized based on their attractiveness as a target for bombing attack scenarios. Some of the relevant attractiveness factors adopted from Ref [13-15] in the present study are as follow:

- The potential to cause maximum damage (causalities, economic loss) including process equipment with significant quantities of flammable or toxic chemicals, the central control room, and utility units.

- Ease of access for adversary, for example: proximity of the assets to the facility boundary, public road, parking lot or dock area

- Recognisability of the target, etc.

\subsection{Developing and analysing the most likely attack scenarios}

IEDs can come in many forms, ranging from a small pipe bomb to a sophisticated device capable of causing massive damages [10]; the extent of damage caused by an IED depends on its size, construction and placement. After possible target assets are identified, a number of attack positions can be selected based on the chemical plant layout and the location of the target assets. For example, a parking lot within a short distance from storage tanks area, or a road between two chemical plants a road near control room or dock areas can be considered as potential attack areas. Table 1 shows a selection of the possible IEDs and their explosive capacity (TNT equivalent mass) based on the maximum amount of material that could reasonably fit into a container or vehicle [10].

\subsubsection{Consequence analysis and domino effect considerations}

In order to evaluate the effects of IEDs on structure and equipment, two parameters are considered: the weapon size, measured in equivalent kilograms of trinitrotoluene (TNT) as 
Table 1: List of possible IEDs and their explosion capacity [10].

\begin{tabular}{ll}
\hline Threat description & Explosive mass (kg) (TNT equivalent) \\
\hline Pipe bomb & 2.3 \\
Suitcase bomb & 23 \\
Sedan & 454 \\
Moving truck & 13608 \\
Semitrailer & 27216 \\
\hline
\end{tabular}

shown in Table 1, and whether the generated peak overpressure exceeds the threshold values needed for causing structural damage $[16,17]$. Several previous publications [18-20] have provided correlations relationships for the shock wave produced by IEDs. In this study, the relationship developed by Bounds [19] is used to evaluate the stand-off distances (i.e. the distance measured from the center of gravity of the explosion to the area that the IED can cause damages). In eqn (1), $P$ is the peak overpressure threshold (bar), $r$ is the stand-off distance $(m)$ and $m_{T N T, e q}$ is the equivalent TNT mass $(\mathrm{kg})$ for a specific improvised device from Table 1 .

$$
P=\frac{m_{T N T, e q}^{\frac{1}{3}}}{r}+4.4 \frac{m_{T N T, e q}^{\frac{2}{3}}}{r^{2}}+14.0 \frac{m_{T N T, e q}}{r^{3}}
$$

The calculated stand-off distances, based on the blast overpressure damage thresholds presented in Table 2, can be used to determine the process equipment being impacted by the IEDs blast waves. The potential damages at process units could result in fire, explosion, and fragment projection that may lead to further damages inside or outside the company premises by triggering domino effects. In this study, to determine which units are possibly impacted by such events, the received fire heat radiation or explosion overpressure by a nearby unit is compared with respective threshold values listed in Table 2.

Furthermore, to estimate the probability of domino effects, the damage probabilities of target units can be calculated by using Probit functions [22]. Having the Probit values, Y calculated from Table 3, the damage probability, D, can be calculated by eqn (2), where $\phi$ is the cumulative density function of a standard normal distribution [23].

$$
\mathrm{D}=\phi(\mathrm{Y}-5) .
$$

Furthermore, based on the calculated D, five cut-off levels for domino effects' probability are defined and categorized in five ranking levels.

Table 2: Damage thresholds due to overpressure and heat radiation for different equipment categories [21]. The same overpressure thresholds are used to determine the possibility of damage due to IED or domino effects.

\begin{tabular}{lll}
\hline Equipment category & Overpressure (bar) & Heat radiation $\left(\mathbf{k W} / \mathbf{m}^{\mathbf{2}}\right)$ \\
\hline Atmospheric vessel & 0.22 & 15 \\
Pressurized vessel (toxic material) & 0.2 & 45 \\
Pressurized vessel (flammable material) & 0.31 & 45 \\
\hline
\end{tabular}


Table 3: Models for domino probability used in this study [22].

\begin{tabular}{lll}
\hline $\begin{array}{l}\text { Escalation vector and } \\
\text { primary scenario }\end{array}$ & Target equipment & Model for domino probability* \\
\hline All radiation scenarios & Atmospheric & $\mathrm{Y}=12.54-1.847 \ln (\mathrm{ttf}) ; \ln (\mathrm{ttf})=-1.128$ \\
& & $\ln (\mathrm{I})-2.667 \times 10^{-5} \mathrm{~V}+9.877$ \\
& Pressurized & $\mathrm{Y}=12.54-1.847 \ln (\mathrm{ttf}) ; \ln (\mathrm{ttf})=-0.947$ \\
& & $\ln (\mathrm{I})+8.835 \mathrm{~V}^{0.032}$ \\
All overpressure sce- & Atmospheric & $\mathrm{Y}=-18.96+2.44 \ln \left(\mathrm{P}_{\mathrm{s}}\right)$ \\
narios & Pressurized & $\mathrm{Y}=-42.44+4.33 \ln \left(\mathrm{P}_{\mathrm{s}}\right)$ \\
\hline
\end{tabular}

*ttf: time to failure(s), I: radiation intensity on target equipment $\left(\mathrm{kW} / \mathrm{m}^{2}\right), \mathrm{V}$ : equipment volume $\left(\mathrm{m}^{3}\right), \mathrm{P}_{\mathrm{s}}=$ peak overpressure on target equipment $(\mathrm{Pa})$.

\subsection{Determining emergency levels}

A ranking criterion is provided to classify the different attack scenarios based on the attack severity and its potential impact on the company, the cluster, and the public. In the criteria table, the attack's consequence is ranked in five levels of severity, similar to the scale used in API 780 [13] from very low to very high. Table 4 provides the details for consequence ranking.

Table 4: Attack scenarios' consequence ranking.

\begin{tabular}{|c|c|c|c|c|c|}
\hline Rank & $\begin{array}{l}\text { Conse- } \\
\text { quence } \\
\text { Category }\end{array}$ & Loss of Life & $\begin{array}{l}\text { Environmental } \\
\text { Impact }\end{array}$ & $\begin{array}{l}\text { Property } \\
\text { Damage } \\
\text { Impact }\end{array}$ & Domino effect \\
\hline 1 & Very low & $\begin{array}{l}\text { No injuries or } \\
\text { fatalities, } \\
\text { First aid required }\end{array}$ & $\begin{array}{l}\text { No environ- } \\
\text { mental impact }\end{array}$ & $\begin{array}{l}\text { Limited local- } \\
\text { ized minor } \\
\text { damage }\end{array}$ & $\begin{array}{l}\text { Unlikely- no } \\
\text { chance of addi- } \\
\text { tional escalation } \\
\text { hazards } \\
(\mathrm{D}<10 \mathrm{E}-6)\end{array}$ \\
\hline 2 & Low & $\begin{array}{l}\text { injuries that are } \\
\text { not widespread but } \\
\text { only in the vicin- } \\
\text { ity of the incident } \\
\text { location }\end{array}$ & $\begin{array}{l}\text { Minor environ- } \\
\text { mental impacts } \\
\text { to immediate } \\
\text { incident site } \\
\text { area only }\end{array}$ & $\begin{array}{l}\text { Significant lo- } \\
\text { calized damage } \\
\text { of some equip- } \\
\text { ment/ buildings, } \\
\text { no major repair } \\
\text { is required. }\end{array}$ & $\begin{array}{l}\text { Moderate- may } \\
\text { cause additional } \\
\text { hazards } \\
(10 \mathrm{E}-6 \leq \mathrm{D}< \\
0.001)\end{array}$ \\
\hline - & & . & . & . & . \\
\hline - & & . & . & . & - \\
\hline - & & . & . & . & - \\
\hline 5 & $\begin{array}{l}\text { Very } \\
\text { High }\end{array}$ & $\begin{array}{l}\text { Possibility of any } \\
\text { offsite fatalities } \\
\text { from large-scale } \\
\text { toxic or flammable } \\
\text { release; possibility } \\
\text { of multiple onsite } \\
\text { fatalities (inside } \\
\text { cluster). }\end{array}$ & $\begin{array}{l}\text { Major environ- } \\
\text { mental impact } \\
\text { on-site and/or } \\
\text { offsite (e.g. } \\
\text { large-scale } \\
\text { toxic contami- } \\
\text { nation of public } \\
\text { waterway) }\end{array}$ & $\begin{array}{l}\text { Major structural } \\
\text { damage } \\
\text { widespread } \\
\text { inside cluster } \\
\text { Extensive } \\
\text { off-site damage }\end{array}$ & $\begin{array}{l}\begin{array}{l}\text { Currently } \\
\text { occurring- }\end{array} \\
(0.5 \leq \mathrm{D} \leq 1.0)\end{array}$ \\
\hline
\end{tabular}


After the attack consequences are analyzed and ranked, a decision tree is used to determine the emergency levels at the companies within the chemical cluster in case of a terrorist attack. Figure 1 shows a part of the developed decision tree if the bombing attack causes fire and explosion. Five emergency levels are defined from level 0 (Informative Alarm) to Level 4 (high-high alarm) based on the severity of the attack. Therefore, the attack's consequence is the key element in evaluating the emergency levels.

It is important not to confuse a 'security response' intended to engage and hopefully neutralize the adversaries with the broader "emergency response" that follows an attack and attempts to reduce the severity of the event and lessen the consequences in terms of loss of life and destruction of property or production capability. In this study, each emergency level indicates responsible people, response strategies and resources.

For example, if a terrorist attack impacts a number of companies within the cluster, the emergency level at each company can be levels 0 or 1 (for a company that is not/little affected and its impact is within the company's boundary), level 2 (for a companies that is moderately affected and it may impact outside the company's premises), level 3 (for a company that is highly affected and its impact reaches other companies or outside the cluster and level 4 (for a company that is severely affected and its impact causes further damage inside/outside the cluster).

\subsection{Alert Level notification system for security response}

When either there is the possibility of an imminent threat or an attack has happened against a particular asset, it should rapidly be communicated across the industrial area to determine appropriate security responses and to increase the protection of target assets and make it difficult for an adversary to harm or damage those assets [24]. A cluster alert notification system

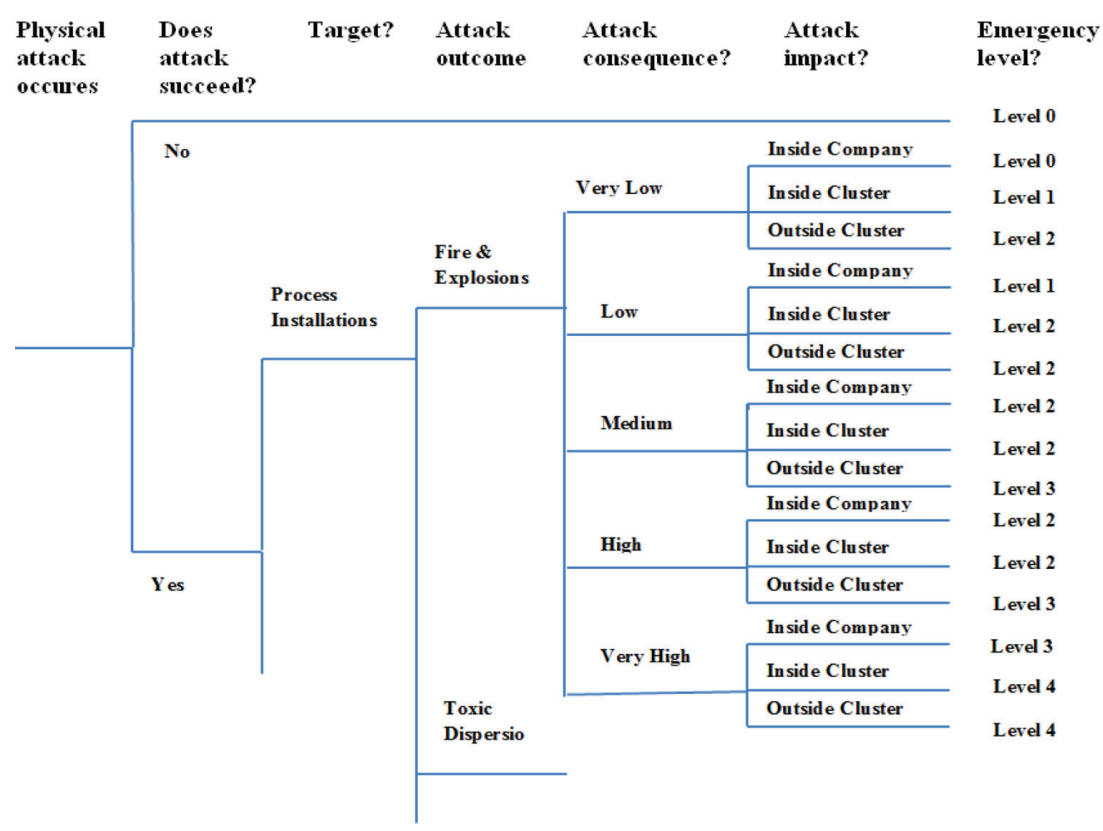

Figure 1: Emergency level decision tree. 
offers help to security decision makers within the chemical cluster in order to analyze and prioritize the information regarding the potential risks at individual plants. According to API/ NPRA Security Vulnerability Assessment [14] each alert level indicates what security measures need to be implemented at the facility based on the level of the threat. In this study for determining the alert levels, two parameters are considered: the emergency level of the actual attack (evaluated from the previous section) and the likelihood of terrorist attack (L) against other critical asset within the cluster.

L can be defined as the multiplication of Threat (T) and asset' Attractiveness (A) [13]. For the purpose of this study, the likelihood of IED attacks are assumed to be very highly denoted with probability of 0.8 , indicating that there is a credible threat against similar assets.

Furthermore, for evaluating A, the most critical asset - from the threat' perspective - at individual companies are identified and the respective ranking level is determined from Table 5. The multiplication of the evaluated ranking probability of A to 0.8 , yields to $\mathrm{L}$ and its respective ranking level is shown in Table 6.

A $5 \times 5$ matrix is developed in order to determine the alert level within the companies of the cluster. The emergency level of an attack is placed on the vertical axis while the likelihood of the attack on the horizontal axis. The matrix is presented in Fig. 2, while Table 7 provides specific definition of each alert level.

Table 5: Target asset attractiveness ranking [13].

\begin{tabular}{llll}
\hline Ranking & Descriptor & $\begin{array}{l}\text { Conditional Proba- } \\
\text { bility of the act }\end{array}$ & Threat interest ranking \\
\hline 1 & Very Low & $0.0 \leq \mathrm{A} \leq 0.2$ & $\begin{array}{l}\text { Threat would have little to no level of inter- } \\
\text { est in the asset. } \\
\text { Threat would have some degree of interest } \\
\text { in the asset, but it is not likely to be of inter- } \\
\text { est compared to other assets. }\end{array}$ \\
3 & Low & $0.2<\mathrm{A} \leq 0.4$ & $\begin{array}{l}\text { Threat would have a moderate degree of } \\
\text { interest in the asset relative to other assets. } \\
\text { Threat would have a high degree of interest } \\
\text { in the asset relative to other assets. } \\
\text { Threat would have a very high degree of }\end{array}$ \\
& High & $0.6<\mathrm{A} \leq 0.8$ & $\begin{array}{l}\text { interest in the asset, and it is a preferred } \\
\text { choice relative to other assets. }\end{array}$ \\
\hline
\end{tabular}

Table 6: Likelihood of attack ranking.

\begin{tabular}{lll}
\hline Ranking & Descriptor & Likelihood of attach \\
\hline 1 & Very low & $0.0 \leq \mathrm{L} \leq 0.2$ \\
2 & Low & $0.2<\mathrm{L} \leq 0.4$ \\
3 & Medium & $0.4<\mathrm{L} \leq 0.6$ \\
4 & High & $0.6<\mathrm{L} \leq 0.8$ \\
5 & Very high & $0.8<\mathrm{L} \leq 1.0$ \\
\hline
\end{tabular}




\begin{tabular}{|c|c|c|c|c|c|}
\hline \multirow{2}{*}{$\begin{array}{c}\text { ER } \\
\text { Level }\end{array}$} & \multicolumn{5}{|c|}{ Likelihood of Attack } \\
\cline { 2 - 6 } & $\mathbf{1}$ & $\mathbf{2}$ & $\mathbf{3}$ & $\mathbf{4}$ & $\mathbf{5}$ \\
\hline $\mathbf{0}$ & $\begin{array}{c}\text { Alert } \\
\text { Level 0 }\end{array}$ & $\begin{array}{c}\text { Alert } \\
\text { Level 1 }\end{array}$ & $\begin{array}{c}\text { Alert } \\
\text { Level 1 }\end{array}$ & $\begin{array}{c}\text { Alert } \\
\text { Level 2 }\end{array}$ & $\begin{array}{c}\text { Alert } \\
\text { Level 2 }\end{array}$ \\
\hline $\mathbf{1}$ & $\begin{array}{c}\text { Alert } \\
\text { Level 1 }\end{array}$ & $\begin{array}{c}\text { Alert } \\
\text { Level 1 }\end{array}$ & $\begin{array}{c}\text { Alert } \\
\text { Level 2 }\end{array}$ & $\begin{array}{c}\text { Alert } \\
\text { Level 2 }\end{array}$ & $\begin{array}{c}\text { Alert } \\
\text { Level 3 }\end{array}$ \\
\hline $\mathbf{2}$ & $\begin{array}{c}\text { Alert } \\
\text { Level 1 }\end{array}$ & $\begin{array}{c}\text { Alert } \\
\text { Level 2 }\end{array}$ & $\begin{array}{c}\text { Alert } \\
\text { Level 2 }\end{array}$ & $\begin{array}{c}\text { Alert } \\
\text { Level 3 }\end{array}$ & $\begin{array}{c}\text { Alert } \\
\text { Level 3 }\end{array}$ \\
\hline $\mathbf{3}$ & $\begin{array}{c}\text { Alert } \\
\text { Level 2 }\end{array}$ & $\begin{array}{c}\text { Alert } \\
\text { Level 2 }\end{array}$ & $\begin{array}{c}\text { Alert } \\
\text { Level 3 }\end{array}$ & $\begin{array}{c}\text { Alert } \\
\text { Level 3 }\end{array}$ & $\begin{array}{c}\text { Alert } \\
\text { Level 4 }\end{array}$ \\
\hline $\mathbf{4}$ & $\begin{array}{c}\text { Alert } \\
\text { Level 2 }\end{array}$ & $\begin{array}{c}\text { Alert } \\
\text { Level 3 }\end{array}$ & $\begin{array}{c}\text { Alert } \\
\text { Level 3 }\end{array}$ & $\begin{array}{c}\text { Alert } \\
\text { Level 4 }\end{array}$ & $\begin{array}{c}\text { Alert } \\
\text { Level 4 }\end{array}$ \\
\hline
\end{tabular}

Figure 2: Alert level decision matrix.

Table 7: Alert level description (Adopted from the U.S. Homeland Security website [25]).

\begin{tabular}{|c|c|c|}
\hline Ranking & Description & Alert level considerations \\
\hline 1 & Low & $\begin{array}{l}\text { Low risk of terrorist attack, normal security posture and con- } \\
\text { duct of business operations }\end{array}$ \\
\hline 2 & Guarded & $\begin{array}{l}\text { General risk of terrorist attack, heightened awareness advi- } \\
\text { sory notice by nearby companies or the cluster security }\end{array}$ \\
\hline 3 & Elevated & $\begin{array}{l}\text { Significant risk of terrorist attack, increasing surveillance of } \\
\text { critical locations. } \\
\text { Coordinating emergency plans as appropriate with nearby } \\
\text { companies }\end{array}$ \\
\hline 4 & High & $\begin{array}{l}\text { High risk of terrorist attacks, extend monitoring capability, } \\
\text { Increase security posture } \\
\text { Preparing to execute contingency procedures (such as evacu- } \\
\text { ation site personnel) } \\
\text { Restricting threatened facility access to essential personnel } \\
\text { only }\end{array}$ \\
\hline 5 & Severe & $\begin{array}{l}\text { Severe risk of terrorist attacks, increasing or redirecting per- } \\
\text { sonnel to address critical emergency needs; } \\
\text { Expand surveillance and response capability, } \\
\text { Assigning emergency response personnel and pre-positioning } \\
\text { and mobilizing specially trained teams or resources }\end{array}$ \\
\hline
\end{tabular}

\subsection{Multi-plant decision matrix}

The identified attack scenarios are placed on the vertical axis, and all the companies within the cluster are placed on the horizontal axis of the matrix. The emergency levels and the alert levels identified from the decision tree and the decision matrix is shown within each cell of the matrix for the companies being either affected by the attack or a likely target for similar attacks. The established multi-plant matrix model is partly depicted in Fig. 3. 


\begin{tabular}{|c|c|c|c|c|c|c|}
\cline { 2 - 7 } \multicolumn{1}{c|}{} & \multicolumn{2}{c|}{ Company A } & \multicolumn{2}{c|}{ Company B } & \multicolumn{2}{c|}{ Company C } \\
\cline { 2 - 7 } \multicolumn{1}{c|}{} & ER level & Alert level & ER level & Alert level & ER level & Alert level \\
\hline SCEN 01 & 1 & 3 & 2 & 2 & 3 & 4 \\
\hline SCEN 02 & 3 & 4 & 1 & 2 & & \\
\hline$\ldots$ & & & & &
\end{tabular}

Figure 3: Multi-Plant decision matrix example.

\section{APPLICATION OF THE METHODOLOGY}

\subsection{Case study}

In order to demonstrate the developed methodology, a chemical industrial area including three companies is taken into account (Fig. 4).

It is considered that terrorists had managed to access Company 3. They used a truck as a Vehicle Borne Improvised Explosive Device (VBIED) containing 13608 kg (TNT equivalent) explosive mass (Table 1); they have the truck parked at attack position 1 (AP1 in Fig. 1), near storage tank area 1 and dock 1 . The impact of the explosion is large enough (eqn 1) to cause damage to nearby process equipment leading to a major fire. For consequence assessment, wind direction of southwest (SW), wind speed of $7 \mathrm{~m} / \mathrm{s}$, stability class $\mathrm{D}$, and ambient temperature of $20^{\circ} \mathrm{C}$ were assumed.

\subsection{Results and discussions}

The potential impact radius of the explosion against the atmospheric storage tanks in area 1 (at Company 3) is calculated as 192 meter, based on the overpressure escalation thresholds of 0.22 bar. The explosion stand-off distance contour is shown in Fig. 5, while Table 8

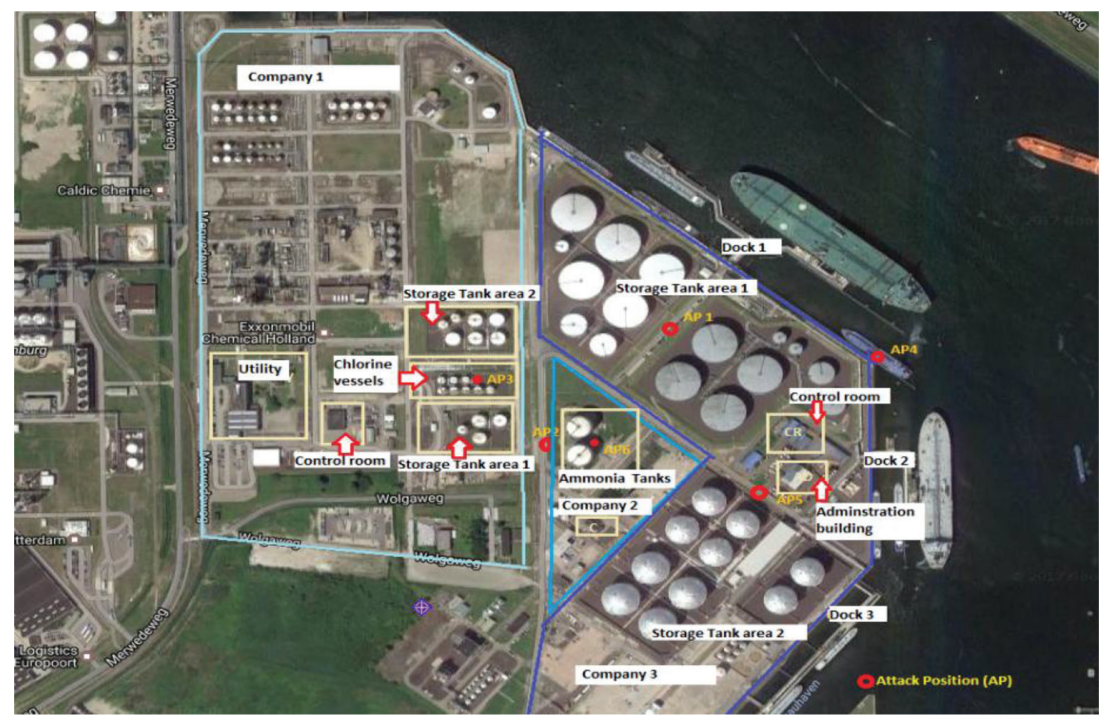

Figure 4: Chemical cluster comprising three chemical plants. 


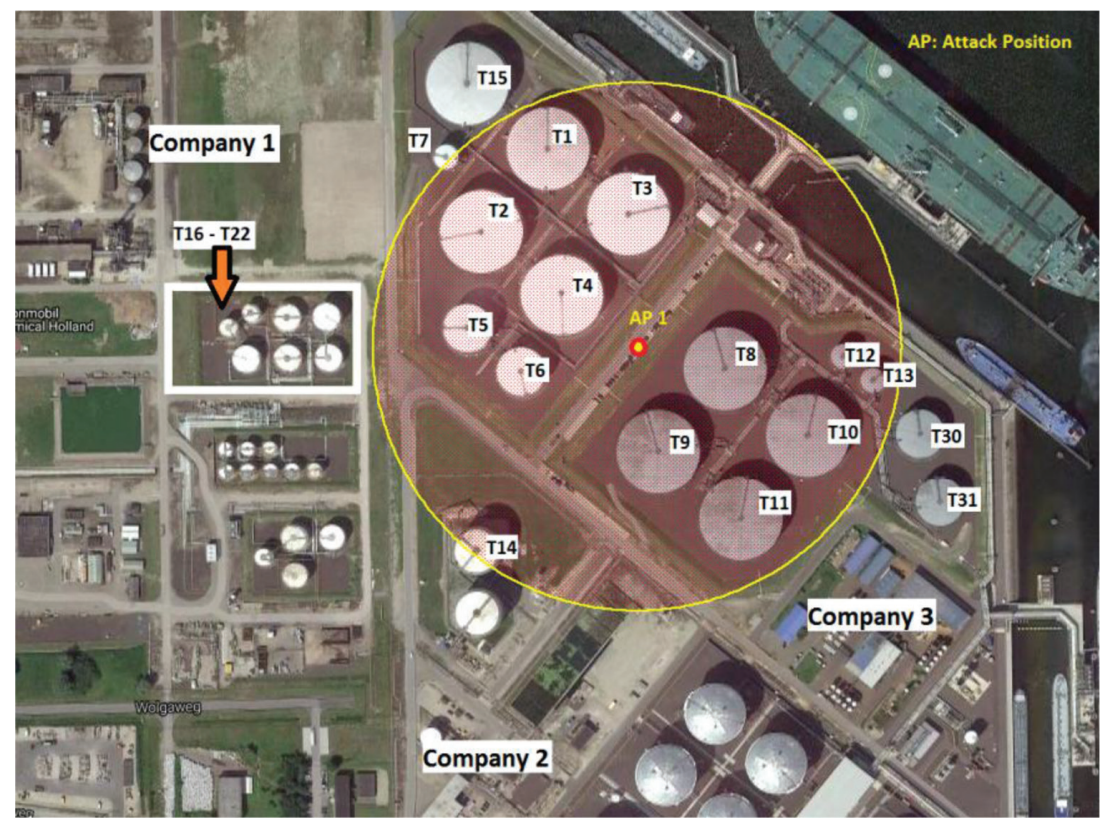

Figure 5: The impact zone ( 0.22 bar) of a VBIED detonation at attack position 1

Table 8: Information related to the equipment that are influenced by VBIED detonation at attack point 1 .

\begin{tabular}{llllll}
\hline \multirow{2}{*}{ Vessel ID } & Vessel Type & Diameter $(\mathbf{m})$ & Height $(\mathbf{m})$ & $\begin{array}{l}\text { Stored Sub- } \\
\text { stance }\end{array}$ & Inventory $\left(\mathbf{m}^{\mathbf{3}}\right)$ \\
\hline T1-T4 & Atmospheric & 60 & 21.2 & Kerosene & 54000 \\
T5-T6 & Atmospheric & 35 & 18 & Kerosene & 15.586 \\
T7 & Atmospheric & 18 & 15.2 & Kerosene & 3.481 \\
T8-T11 & Atmospheric & 60 & 21.9 & Benzene & 55800 \\
T12-T13 & Atmospheric & 18 & 15.2 & Benzene & 1,934 \\
T14 & Atmospheric & 30 & 21.24 & Ammonia & 13500 \\
\hline
\end{tabular}

summarizes the associated equipment items, which receive explosion overpressure higher than or equal to the correspondent threshold value. As indicated in Fig. 6, the attack not only has severe impact inside Company 3, it also affects the Northern part of Company 2. It is assumed that the damaged units by blast overpressure in Company 3 will initiate pool fires that are able to impact other companies within the cluster. The consequence of the pool fire scenarios are calculated (using ALOHA software) on the nearby units exposed to high heat radiation levels (greater than or equal to the threshold values in Table 2). The primary pool fire scenarios has the potential to cause further damage and trigger secondary scenarios (such as pool fire, tank fire, explosions, etc.) on target equipment. For example, the pool fire at tank T2 will affect several equipment (T16-T22) in Company 1. The results of the primary pool fire scenarios and the domino probabilities of affected units are reported in Table 9. 
Table 9: Primary and secondary scenarios triggered by VBIED detonation at attack point 1 (AP1).

\begin{tabular}{|c|c|c|c|c|c|c|c|}
\hline $\begin{array}{l}\text { Pri- } \\
\text { mary } \\
\text { event }\end{array}$ & $\begin{array}{l}\text { Escala- } \\
\text { tion } \\
\text { Vector }\end{array}$ & $\begin{array}{l}\text { Affected } \\
\text { Units }\end{array}$ & $\begin{array}{l}\text { Primary } \\
\text { Scenario }\end{array}$ & $\begin{array}{l}\text { Escalation } \\
\text { vector }\end{array}$ & $\begin{array}{l}\text { Second- } \\
\text { ary } \\
\text { units }\end{array}$ & $\begin{array}{l}\text { Damage } \\
\text { Probabil- } \\
\text { ity }\end{array}$ & $\begin{array}{l}\text { Possible } \\
\text { Secondary } \\
\text { Scenarios }\end{array}$ \\
\hline \multirow{3}{*}{$\begin{array}{l}\text { VBIED } \\
\text { Blast at } \\
\text { AP1 }\end{array}$} & $\begin{array}{l}\text { Over- } \\
\text { pressure }\end{array}$ & $\mathrm{T} 1-\mathrm{T} 7$ & Pool fire & Radiation & $\begin{array}{l}\mathrm{T} 15, \\
\mathrm{~T} 16-\mathrm{T} 22\end{array}$ & $\begin{array}{l}0.022 \\
7.35 \mathrm{E}-7\end{array}$ & $\begin{array}{l}\text { Pool fire, } \\
\text { Tank fire, }\end{array}$ \\
\hline & $\begin{array}{l}\text { Over-pres- } \\
\text { sure }\end{array}$ & T8-T13 & Pool fire & Radiation & T30, T31 & 0.005 & Pool fire \\
\hline & $\begin{array}{l}\text { Over- } \\
\text { pressure }\end{array}$ & $\mathrm{T} 14$ & $\begin{array}{l}\text { Leakage/ } \\
\text { toxic } \\
\text { release }\end{array}$ & - & - & & - \\
\hline
\end{tabular}

Besides the damage to the properties and equipment, there would be causalities not only at Company 3 but also the other companies within the cluster. The off-site (outside cluster) causalities may happen due to indirect effects of the attack. For example the blast overpressure and projections may cause a major leakage at Ammonia storage tank (T14). The personnel of passing ships or boats in the nearby waterway may be exposed to high amounts of the toxic gas (within the AEGL-2) and would experience serious or irreversible adverse health effects. Also the gas cloud (AEGL-1) is likely to reach the residential area outside the cluster $(10 \mathrm{~km})$, causing notable discomfort, irritation and reversible effects to the public.

Using Table 2 and the decision tree in Fig. 1, the emergency levels are determined as follow:

Company 1 is not directly impacted by the attack, however the results from Table 9 indicates that several units in this plant are exposed to high levels of heat radiation and the domino effect is likely. The consequence ranking is medium, and it will not cause further adverse impacts outside the company premises. Therefore, the emergency level can be identified as 2 .

Company 2 is directly influenced by the blast overpressure, and T14 (Ammonia storage tank) is damaged and may cause huge impact both inside and outside the cluster. Therefore, the emergency level is 3 .

A large part of Company 3 is damaged by the attack, there is a severe environmental and property damage, and domino effect is almost certain within the company. The consequence is very high, and Dock 1 area and the nearby waterway are impacted accordingly. Therefore, the emergency level is 4 .

Since the threat $(\mathrm{T})$ for this security event is considered very high for each chemical plant with the probability 0.8 , and the most attractive target assets at the three companies are identified, the likelihood of attack can be calculated as in Table 10.

After the emergency levels and the likelihood of attack for each company is evaluated, the alert levels can be predicted using the decision matrix in Fig. 3. The final result is presented in the multi-plant decision matrix in Fig. 6. 
Table 10: Likelihood of attack at the chemical cluster.

\begin{tabular}{|c|c|c|c|c|c|}
\hline $\begin{array}{l}\text { Com- } \\
\text { pany }\end{array}$ & $\begin{array}{l}\text { Most critical Target } \\
\text { Asset from threat's } \\
\text { perspective }\end{array}$ & $\begin{array}{l}\text { Attractiveness } \\
\text { (A) probability }\end{array}$ & $\begin{array}{l}\text { Threat }(\mathrm{T}) \\
\text { probability }\end{array}$ & $\begin{array}{l}\text { Likelihood of } \\
\text { attack } \\
(\mathrm{L}=\mathrm{A} \times \mathrm{T})\end{array}$ & $\begin{array}{l}\text { Likelihood of } \\
\text { attack } \\
\text { ranking }\end{array}$ \\
\hline 1 & $\begin{array}{l}\text { Chlorine pressurized } \\
\text { vessels }\end{array}$ & 1.0 & 0.8 & 0.8 & 5- Very High \\
\hline 2 & Ammonia Tank & 0.8 & 0.8 & 0.64 & 4- High \\
\hline 3 & Tank area $1 \& 2$ & 0.9 & 0.8 & 0.72 & 4- High \\
\hline
\end{tabular}

\begin{tabular}{|l|c|c|c|c|c|c|}
\cline { 2 - 7 } \multicolumn{1}{c|}{} & \multicolumn{2}{c|}{ Company 1 } & \multicolumn{2}{c|}{ Company 2 } & \multicolumn{2}{c|}{ Company 3 } \\
\cline { 2 - 7 } & $\begin{array}{c}\text { ER } \\
\text { Level }\end{array}$ & $\begin{array}{c}\text { Alert } \\
\text { Level }\end{array}$ & $\begin{array}{c}\text { ER } \\
\text { Level }\end{array}$ & $\begin{array}{c}\text { Alert } \\
\text { Level }\end{array}$ & $\begin{array}{c}\text { ER } \\
\text { level }\end{array}$ & $\begin{array}{c}\text { Alert } \\
\text { level }\end{array}$ \\
\hline $\begin{array}{l}\text { Attack at the } \\
\text { car park area in } \\
\text { Company 3 }\end{array}$ & 2 & 3 & 4 & 3 & 4 & 4 \\
\hline
\end{tabular}

Figure 6: The multi-plant decision matrix.

\section{CONCLUSIONS}

Chemical industrial areas can be critical targets to terrorist attacks with improvised explosive devices. Such attacks may affect several neighbouring facilities, the whole cluster and even the nearby communities. In the present study, in order to help emergency responders and security decision makers within the chemical cluster an efficient cluster-wise decision tool, comprising a decision tree and decision matrices, was developed that determines the emergency and alert levels at each company. Each identified emergency level identifies the potential actions that an individual could adopt to prepare for and respond to a terrorist attack scenario. Likewise, each alert level indicates to what extent to increase the security of other critical assets due to either the possibility of an imminent threat or the occurrence of an actual attack against a particular asset.

\section{ACKNOWLEDGEMENTS}

The authors acknowledge the financial support provided by Leiden-Delft-Erasmus Centre for Safety and Security (LDE-CSS), The Netherlands.

\section{REFERENCES}

[1] Baybutt, P., Strategies for protecting process plants against terrorism, sabotage and other criminal acts. Homeland Defence Journal, 2, pp. 1-7, 2003.

[2] Belke, J.C., Chemical accident risks in US industry-A preliminary analysis of accident risk data from US hazardous chemical facilities. Loss Prevention and Safety Promotion in the Process Industries, 2001, pp. 1275-1314, 2000.

https://doi.org/10.1016/B978-044450699-3/50041-0 
[3] Bajpai, S. \& Gupta, J.P., Site security for chemical process industries. Journal of Loss Prevention in the Process Industries, 18(4), pp. 301-309, 2005.

https://doi.org/10.1016/j.jlp.2005.06.011

[4] Arnold, J.L., Tsai, M.C., Halpern, P., Smithline, H., Stok, E. \& Ersoy, G., Mass-casualty, terrorist bombings: epidemiological outcomes, resource utilization, and time course of emergency needs (Part I). Prehospital and Disaster Medicine, 18(3), pp. 220-234, 2003. https://doi.org/10.1017/s1049023x00001096

[5] Landucci, G., Reniers, G., Cozzani, V. \& Salzano, E., Vulnerability of industrial facilities to attacks with improvised explosive devices aimed at triggering domino scenarios. Reliability Engineering \& System Safety, 143, pp. 53-62, 2015.

https://doi.org/10.1016/j.ress.2015.03.004

[6] Pavlova, Y. \& Reniers, G., A sequential-move game for enhancing safety and security cooperation within chemical clusters. Journal of Hazardous Materials, 186(1), pp. 401-406, 2011.

https://doi.org/10.1016/j.jhazmat.2010.11.013

[7] Reniers, G. \& Soudan, K., A game-theoretical approach for reciprocal security-related prevention investment decisions. Reliability Engineering \& System Safety, 95(1), pp. 1-9, 2010.

https://doi.org/10.1016/j.ress.2009.07.001

[8] Suicide bombers in boat attack on Iraq oil terminal, available at https://www.theguardian.com/world/2004/apr/25/iraq2

[9] ISIS launches attacks at Iraq's largest oil refinery, available at http://english.alarabiya.net/ en/News/middle-east/2015/04/12/ISIS-militants-attack-Iraq-s-largest-oil-refinery.html

[10] Kennett, M., Letvin, E., Chipley, M. \& Ryan, T., Federal Emergency Management Agency (FEMA), US Department of Homeland Security, United States of America, US Deptartment of veterans affairs and United States of America, risk assessment: a how-to guide to mitigate potential terrorist attacks against buildings. FEMA Risk Management Series, 2005.

[11] Bajpai, S. \& Gupta, J.P., Terror-proofing chemical process industries. Process Safety and Environmental Protection, 85(6), pp. 559-565, 2007.

https://doi.org/10.1205/psep06046

[12] Site security guidelines for the U.S. chemical industry, 2001, http://www.ohlhausen. com/wp-content/uploads/2013/07/chemical-site-guidelines.pdf

[13] API Recommended Practice 780, Security risk assessment methodology for the petroleum and petrochemical industries, document draft. Washington, DC: American Petroleum Institute, 2012.

[14] API/NPRA, Security vulnerability assessment. Washington, DC: American Petroleum Institute Publishing Services, 2003.

[15] Argenti, F., Landucci, G., Spadoni, G. \& Cozzani, V., The assessment of the attractiveness of process facilities to terrorist attacks. Safety Science, 77, pp. 169-181, 2015. https://doi.org/10.1016/j.ssci.2015.02.013

[16] Salzano, E. \& Cozzani, V., The analysis of domino accidents triggered by vapor cloud explosions. Reliability Engineering \& System Safety, 90(2), pp. 271-284, 2005. https://doi.org/10.1016/j.ress.2004.11.012

[17] Cozzani, V., Gubinelli, G. \& Salzano, E., Escalation thresholds in the assessment of domino accidental events. Journal of Hazardous Materials, 129(1), pp. 1-21, 2006. https://doi.org/10.1016/j.jhazmat.2005.08.012 
[18] Bounds, W.L., Design of blast resistant buildings in petrochemical facilities. ASCE Publications, Reston, VA, 1997.

[19] Alonso, F.D., Ferradas, E.G., Minarro, M.D., Aznar, A.M., Gimeno, J.R. \& Pérez, J.F.S., Consequence analysis by means of characteristic curves to determine the damage to buildings from the detonation of explosive substances as a function of TNT equivalence. Journal of Loss Prevention in the Process Industries, 21(1), pp. 74-81, 2008. https://doi.org/10.1016/j.jlp.2007.08.002

[20] Price, M.A. \& Ghee, A.H., Modeling for detonation and energy release from peroxides and non-ideal improvised explosives. Central European Journal of Energetic Materials, 6(3-4), pp. 239-254, 2009.

[21] Cozzani, V., Antonioni, G., Landucci, G., Tugnoli, A., Bonvicini, S. \& Spadoni, G., Quantitative assessment of domino and NaTech scenarios in complex industrial areas. Journal of Loss Prevention in the Process Industries, 28, pp. 10-22, 2014. https://doi.org/10.1016/j.jlp.2013.07.009

[22] Cozzani, V., Gubinelli, G., Antonioni, G., Spadoni, G. \& Zanelli, S., The assessment of risk caused by domino effect in quantitative area risk analysis. Journal of Hazardous Materials, 127(1), pp. 14-30, 2005. https://doi.org/10.1016/j.jhazmat.2005.07.003

[23] Khakzad, N., Khan, F., Amyotte, P. \& Cozzani, V., Domino effect analysis using Bayesian networks. Risk Analysis, 33(2), pp. 292-306, 2013. https://doi.org/10.1111/j.1539-6924.2012.01854.x

[24] Sullivant, J., Building a corporate culture of security: strategies for strengthening organizational resiliency. Butterworth-Heinemann, 2016.

[25] National terrorism advisory system, available at https://www.dhs.gov/national-terrorism-advisory-system 